\title{
The Long-Term Perspective of Human Impact on Landscape for Environmental Change (LoTEC) and Sustainability: From Botany to the Interdisciplinary Approach
}

\author{
Anna Maria Mercuri * and Assunta Florenzano \\ Laboratorio di Palinologia e Paleobotanica, Dipartimento Scienze della Vita, Università degli Studi di Modena e \\ Reggio Emilia, 41100 Modena, Italy; assunta.florenzano@unimore.it \\ * Correspondence: annamaria.mercuri@unimore.it; Tel.: +39-059-205-8275
}

Received: 8 January 2019; Accepted: 9 January 2019; Published: 15 January 2019

This is not the first time the Earth has to experience dramatic environmental and climate changes but this seems to be the first time that a living species - humanity —is able to understand that great changes are taking place rapidly and that probably natural and anthropogenic forces are involved in the process that is under way. Interdisciplinary research is central to successfully promote sustainable development. The understanding of the Long-Term Environmental Changes_LoTEC—is urgent to facilitate sustainable development and it is based on the knowledge and description of environments at subsequent phases and degrees of human impact. Within the domains of Sustainability [1], this is a special matter for environmental and ecological studies. Many different perspectives are involved which study botany and have the goal of improving sustainability through the understanding of the role of people in shaping current landforms and landscapes, the importance of social and policy choices in the loss of species and equilibrium of old or new ecosystems, the correct application of scientific discoveries for renewable agriculture (e.g., [2]) or biodiversity conservation [3,4], new ideas for education and training of new generations working on/with the environment $[5,6]$. Not only crop, garden and decoration plant species but also wild plants are recognized as having an invaluable importance for new proposals for future agriculture [7] and additional ecosystem and cultural services exploitation [8]. Human culture is largely based on plants, which have always been at the center of past and present food, medicine, shelter, fuel, dress, feed, forage, and art, belief, feasts and traditions. Botanical studies have the largest potentiality to study the LoTEC with details on the different chronological phases, and regional features. Several studies have been, and are, carried out through paleoecology [9], geoarchaeology [10], agroecology [11], ethnobotany [12], archaeology [13], and demography [14]. Palynology is among the best tools to study high-resolution sequences formed under natural and anthropic (cultural) forces $[15,16]$, and LoTEC can be studied by characterizing human action on tree crops and synanthropic wild plants, which prefer to grow in rural and urban environments (e.g., in the Mediterranean area: references [17-19]). Many studies outline the relationships between the rise and fall of past cultures [20-22] connecting the environmental changes with potential crisis of past societies (Terramare in N Italy: [23]; Negev in Israel: [24]; Beyşehir Occupation phase in southwest Turkey [25]; Khabur collapse in north-eastern Syria [26]).

Sustainable agriculture and land management are among the key themes that must be deepened in a long-term perspective. Palaeoenvironmental research has demonstrated that people have adopted a diffused pattern of land use involving a combination of diverse activities, using trees-crops-domesticate animals with a combination of wood exploitation, field cultivation and animal breeding (e.g., since the Neolithic in the Mediterranean area). The multifunctional land-use, adopted for millennia [27], seems to be the best way to develop our economy in the future. Moreover, the knowledge of the 
past is the most reliable basis to identify the vocation of different lands for future developments. Archaeobotany can give fundamental information about the presence of people and various land uses along past millennia, in prehistoric and historic centuries [28-32]. For several reasons, however, the integration between results from past and present contexts is negligible, and it is more common to find papers written by archaeobotanists to botanists [33], by historians to palaeoecologists [34], and by palaeoecologists to ecologists [35], rather than by ecologists towards palaeoecologists [36].

This Special Issue seeks to engage an interdisciplinary dialogue on the dynamic interactions between nature and society, focusing on long-term environmental data as an essential tool to better-informed landscape management decisions that develop equilibrium between conservation and sustainable resources exploitation. In particular, this SI intends to provide papers from very different approaches studying the long term human impacts, possibly among the rare cases of diverse expertise and consideration on what 'human impact' means and what 'long-term' means (Figure 1).

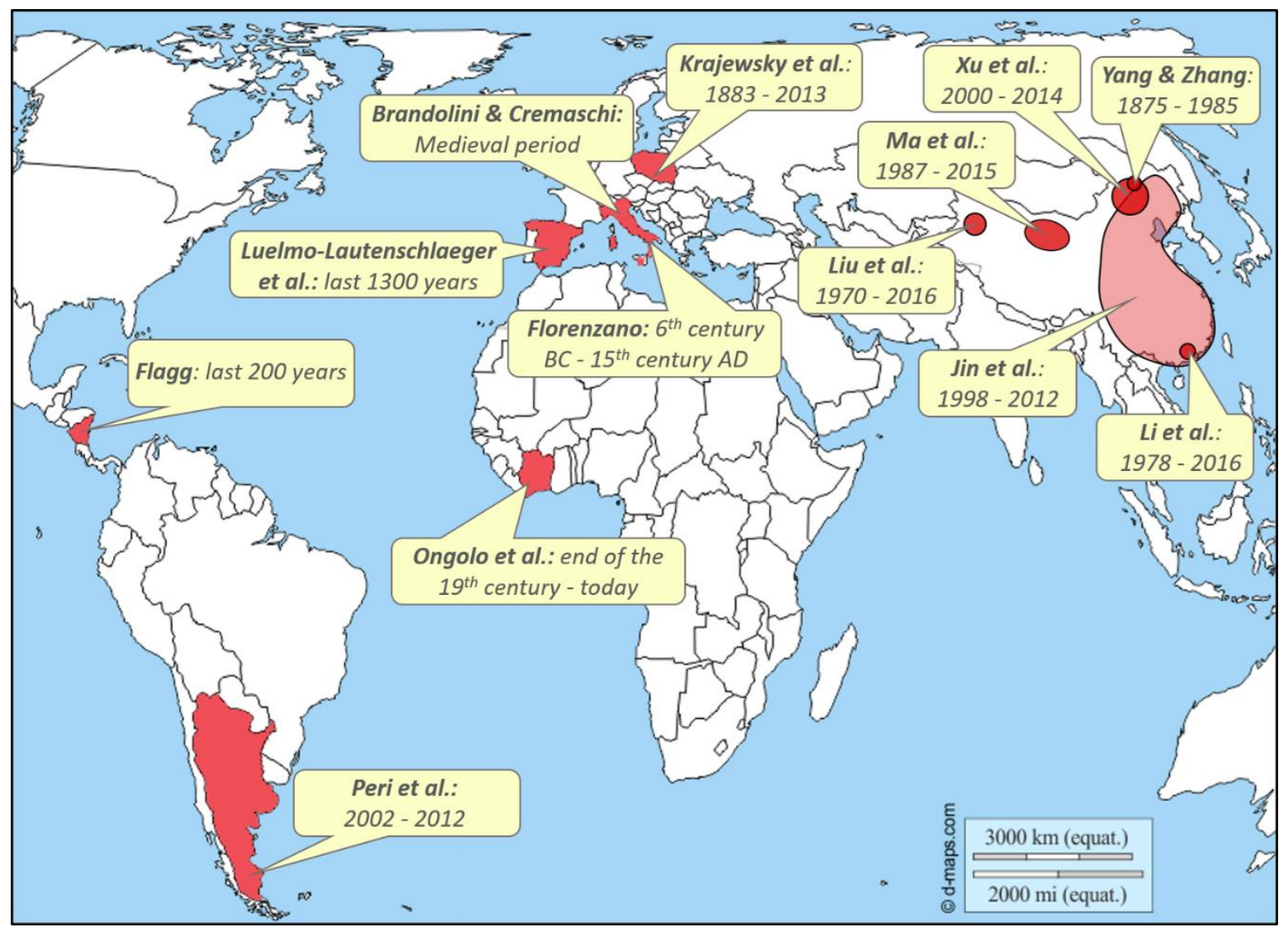

Figure 1. Location map of the study areas (in red) of the 13 research articles included in this Special Issue. For each country, a label showing the first Author names and the time frame of the research has been added (map modified from d-maps.com: free maps).

The Special Issue guest editors are archaeobotanists/palynologists and their 'long term' is on the range of millennia. Three papers-by Luelmo-Lautenschlaeger and colleagues, by Florenzano, and by Brandolini and Cremaschi-introduce the palaeoecological perspective focusing on the last millennia of southern Europe. Luelmo-Lautenschlaeger et al. present a palynological study of the 'mid-mountains' ecosystem dynamics driven by the climate and human actions in the Toledo Mountains, central Spain. This research, based on the multi-proxy study of the Bermú palaeoenvironmental record, is essential to understanding the long-term complex interactions between environment and highland people that led to the current high-value cultural landscape in that area. The same approach has been employed by Florenzano to detail past land-uses and pastoral activities in Basilicata, a region of southern Italy 
where animal breeding and pastoralism have a long tradition. Her study is intended to improve the awareness about biodiversity and human impact shaping the modern landscape of the region, and the Mediterranean landscapes. Brandolini and Cremaschi analyze the fluvial landscape development in the Central Po Plain (North Italy) by integrating geomorphological, archaeological and historical data. The analysis of the relationships between fluvial palaeoenvironments and past human activities is crucial for future sustainable management of these complex systems in order to maintain both their evolutionary processes and the fragile dynamic equilibrium of floodplains.

Besides this palaeoecological/palaeoenvironmental research, several studies on most recent landscape transformations are part of the collection of papers in the Special Issue. They offer a broad sweep across many of the current environmental issues by following different approaches and methodologies.

Krajewsky et al. detect the driving forces behind landscape changes of Ślęża Landscape Park, Poland. Their preliminary study on natural and socio-economic factors of changes introduces a new tool for assessing the level of historical landscape transformation (Landscape Change Index-LCI) and provides the first insights into the forest area transformation during the last 140 years.

The research by Jin et al. focuses on the study of the main factors (spatio-temporal variations of climate factors and urbanization impact) which govern the urban ecosystem, and explore their correlations. The authors utilize data from 71 large cities of eastern China using a 15-year window, estimating the impact of urbanization on vegetation change in urban and suburban areas. The main outcomes indicate that vegetation cover in cities has been negatively impacted by urbanization, whose effects were more severe in urban areas than in suburban spaces.

Yang and Zhang present an historical reconstruction of arable land based on the distribution of settlements and the farming radius in Zhenlai County, northeast China. This research contributes to the currently available arable land reconstruction studies applying a methodological approach combining the digitized land cover/use data from topographic maps, and the settlement information obtained from toponymy or gazetteer records within the research region. This "cultivation-settlement ratio-based" method is useful to reconstruct historical changes in arable land which could reflect human activities on environmental changes.

The paper by Ma et al. deals with an evaluation model for land-use intensity and its temporal-spatial variation in Shule River Basin, Gansu Province of central China. Land-use intensity change can be a useful indicator of the human impact on land-cover and its variation has important influence on biodiversity and ecosystem service function. These authors evaluate both the comprehensive land-use and the use intensity of a single type of land (artificial and semi artificial land-use) over a period of about 30 years and in doing so reveal some changes in the land-use structure in the study region.

$\mathrm{Xu}$ et al. estimate the human-induced vegetation change in arid and semi-arid ecosystems, which are extremely sensitive to external interference (especially over-grazing, over-farming and deforestation) and therefore need sustainable land use policies and programs. The research focuses on the discrimination of significant human-induced changes from 2000 to 2014 in two study areas with different levels of human influence in the Horqin Sandy Land, Northeast China. Climate and human actions have been responsible for the vegetation decrease in both regions, and human factors driving the changes (management of grassland, over-grazing, farming) varied in the two study areas.

Grazing pressure and land management are also recognized as the main factors influencing rangeland ecosystem functioning. Soil Organic Carbon (SOC) content in rangeland is essential for the capacity of the land to sustain plant and animal productivity, and mainly depends on environmental factors and land-use types. In their study, Peri et al. use climatic, topographic and vegetation variables to develop a model of SOC stocks in the Santa Cruz province (South Patagonia), useful tool to assess the sustainability of land management at local scale.

Liu et al. evaluate the expansion dynamics of agricultural oasis and its impact on oasis landscape patterns in Qira oasis, in the southern margin of Tarim basin, Northwest China, by using multi-source 
satellite images. The understanding of relations between agricultural oasis change and its landscape pattern is crucial to ensure that agricultural oasis sustainability persists in this arid region.

Multi-source remote sensing images are also used by $\mathrm{Li}$ et al. to monitor the evolution of dike-ponds in Shunde District of Southeast China. The authors examine both the spatial evolution and dynamics of change of dike-ponds to gain insights on the reduction/conversion of inland freshwater ecosystem due to the nowadays invasion of other land-use types.

The last two papers deal with the understanding of contemporary environmental issues through an analysis of long-term, historical, social, environmental, and political data. Flagg presents the case study on Costa Rica's 2007 mitigation pledge within a nearly 200-year long history of actions undertaken by the Costa Rica state. The human-environment interactions are investigated through an analysis of interview data, archival research, and secondary data. Ongolo et al. examine the sustainability of forest ecosystems in Côte d'Ivoire through an historic contextualisation of forestland use policies in Sub-Saharan Africa. The authors use a twofold approach that combines analysis of the qualitative data (from scientific literature and through historiographic revision of landscape transformations) together with a descriptive statistical analysis of the quantitative data (e.g., from scientific empirical research and FAO data). Both articles highlight the importance of using long-term historical data to understand environmental issues, and stress the prominent role of political elites and policy-makers in the present-day biodiversity and sustainability.

The research studies included in this Special Issue point to the fundamental contribution of the knowledge of past environmental history to conscious and efficient environment conservation and management. Therefore, the long-term perspective of the dynamics which govern the human-climate ecosystem is becoming one of the main focuses and a paramount interest in biological and earth system sciences. Modern biodiversity is the result of the long-term shaping that humans and climate made on vegetation, soils and landforms. Climate change and human impact are predicted to become significant risks to global biodiversity. Multidisciplinary bio-geo-archaeo investigations on the underlying processes of human impact on landscape are crucial to allow us to envisage possible future scenarios of biosphere responses to global warming and biodiversity losses.

Author Contributions: A.M.M. and A.F. contributed equally to this Editorial. A.M.M. and A.F. co-edited the Special Issue on "The Long-Term Perspective of Human Impact on Landscape For Environmental Change and Sustainability" (https://www.mdpi.com/journal/sustainability/special_issues/Human_Impact_on_Landscape).

Acknowledgments: We are very grateful to the different authors for their valuable contribution to this special issue on LOTEC and Sustainability. We warmly thank all the reviewers who dedicated time and assisted in improving the manuscripts.

Conflicts of Interest: The authors declare no conflict of interest.

\section{References}

1. $\quad$ Passet, R. L'Économique et le vivant; Payot: Paris, France, 1979; ISBN 9782717831047.

2. Beckford, C.L. Sustainable agriculture and innovation adoption in a tropical small-scale food production system: The case of Yam Minisetts in Jamaica. Sustainability 2009, 1, 81-96. [CrossRef]

3. Rogstad, S.H.; Pelikan, S. Plant species restoration: effects of different founding patterns on sustaining future population size and genetic diversity. Sustainability 2013, 5, 1304-1316. [CrossRef]

4. Fernández-Llamazares, Á.; Belmonte, J.; Boada, M.; Fraixedas, S. Airborne pollen records and their potential applications to the conservation of biodiversity. Aerobiologia 2014, 30, 111-122. [CrossRef]

5. Galaz, C.M.; Weil, C.G. University teachers' conceptions about science and science learning, and how they address the promotion of scientific skills in biology teacher-training. Enseñanza de las Ciencias 2014, 32, 51-81. [CrossRef]

6. Acevedo-Díaz, J.A.; García-Carmona, A. "Something old, something new, something borrowed". Trends on the nature of science in science education. Revista Eureka sobre Enseñanza y Divulgación de las Ciencias 2016, 12, 3-19. [CrossRef] 
7. Mercuri, A.M.; Fornaciari, R.; Gallinaro, M.; Vanin, S.; di Lernia, S. Plant behaviour from human imprints and the cultivation of wild cereals in Holocene Sahara. Nature Plants 2018, 4, 71-81. [CrossRef] [PubMed] 
8. Khoury, C.K.; Amariles, D.; Soto, J.S.; Diaz, M.V.; Sotelo, S.; Sosa, C.C.; Ramírez-Villegas, J.; Achicanoy, H.A.; Velásquez-Tibatá, J.; Guarino, L.; et al. Comprehensiveness of conservation of useful wild plants: An operational indicator for biodiversity and sustainable development targets. Ecol. Indic. 2019, 98, 420-429. [CrossRef]

9. Davies, A.L.; Bunting, M.J. Applications of paleoecology in conservation. Open Ecol. J. 2010, 3, 54-67. [CrossRef]

10. Cremaschi, M.; Zerboni, A.; Mercuri, A.M.; Olmi, L.; Biagetti, S.; di Lernia, S. Takarkori rock shelter (SW Libya): An archive of Holocene climate and environmental changes in the central Sahara. Quat. Sci. Rev. 2014, 101, 36-60. [CrossRef]

11. Wezel, A.; Bellon, S. Mapping Agroecology in Europe. New Developments and Applications. Sustainability 2018, 10, 2751. [CrossRef]

12. Sheng-Ji, P. Ethnobotanical approaches of traditional medicine studies: Some experiences from Asia. Pharm. Biol. 2001, 39, 74-79. [CrossRef] [PubMed]

13. Day, J. Botany meets archaeology: People and plants in the past. J. Exp. Bot. 2013, 64, 5805-5816. [CrossRef] [PubMed]

14. Dean, J.S.; Euler, R.C.; Gumerman, G.J.; Plog, F.; Hevly, R.H.; Karlstrom, T.N.V. Human Behavior, Demography, and Paleoenvironment on the Colorado Plateaus. Am. Antiq. 1985, 50, 537-554. [CrossRef]

15. Mercuri, A.M. Genesis and evolution of the cultural landscape in central Mediterranean: The 'where, when and how' through the palynological approach. Landscape Ecol. 2014, 29, 1799-1810. [CrossRef]

16. Edwards, K.J.; Fyfe, R.M.; Jackson, S.T. The first 100 years of pollen analysis. Nature Plants 2017, 3, 17001. [CrossRef]

17. Kouli, K.; Masi, A.; Mercuri, A.M.; Florenzano, A.; Sadori, L. Regional Vegetation Histories: An Overview of the Pollen Evidence from the Central Mediterranean. Late Antiq. Archaeol. 2018, 11, 69-82. [CrossRef]

18. Mercuri, A.M.; Bandini Mazzanti, M.; Florenzano, A.; Montecchi, M.C.; Rattighieri, E.; Torri, P. Anthropogenic Pollen Indicators (API) from archaeological sites as local evidence of human-induced environments in the Italian peninsula. Ann. Bot. 2013, 3, 143-153. [CrossRef]

19. Mercuri, A.M.; Bandini Mazzanti, M.; Florenzano, A.; Montecchi, M.C.; Rattighieri, E. Olea, Juglans and Castanea: The OJC group as pollen evidence of the development of human-induced environments in the Italian peninsula. Quatern. Int. 2013, 303, 24-42. [CrossRef]

20. Mercuri, A.M.; Sadori, L.; Uzquiano, P. Mediterranean and North-African cultural adaptations to mid-Holocene environmental and climatic changes. Holocene 2011, 21, 189-206. [CrossRef]

21. Zanchetta, G.; Bini, M.; Di Vito, M.A.; Sulpizio, R.; Sadori, L. Tephrostratigraphy of paleoclimatic archives in central Mediterranean during the Bronze Age. Quatern. Int. 2018. [CrossRef]

22. Storozum, M.J.; Zhen, Q.; Xiaolin, R.; Haiming, L.; Yifu, C.; Kui, F.; Haiwang, L. The collapse of the North Song dynasty and the AD 1048-1128 Yellow River floods: Geoarchaeological evidence from northern Henan Province, China. Holocene 2018, 28, 1759-1770. [CrossRef]

23. Cremaschi, M.; Mercuri, A.M.; Torri, P.; Florenzano, A.; Pizzi, C.; Marchesini, M.; Zerboni, A. Climate change versus land management in the Po Plain (Northern Italy) during the Bronze Age: New insights from the VP/VG sequence of the Terramara Santa Rosa di Poviglio. Quat. Sci. Rev. 2016, 136, 153-172. [CrossRef]

24. Stavi, I.; Rozenberg, T.; Al-Ashhab, A.; Argaman, E.; Groner, E. Failure and collapse of ancient agricultural stone terraces: On-Site effects on soil and vegetation. Water 2018, 10, 1400. [CrossRef]

25. Roberts, N.; Esatwood, W.J.; Lamb, H.; Tibby, J.C. The age and causes of mid-late Holocene environmental change in Southwestern Turkey. In Third Millennium BC Climate Change and Old World Collapse (NATO ASI Series I: Global Environmental Change); Nüzhet Dalles, H., Kukla, G., Weiss, H., Eds.; Springer: Berlin, Germany, 1997; Volume 49, pp. 409-429. ISBN 9783642644764.

26. Koliński, R. On grain, bones, and Khabur collapse. In Folia Praehistorica Posnaniensia; Instytut Praehistiorii, Uam Poznań: Poznań, Poland, 2011; Volume XVI, pp. 201-217. ISBN 9788323224358.

27. Mercuri, A.M.; Florenzano, A.; Burjachs, F.; Giardini, M.; Kouli, K.; Masi, A.; Picornell-Gelabert, L.; Revelles, J.; Sadori, L.; Servera-Vives, G.; et al. From influence to impact: The multifunctional land-use in Mediterranean prehistory emerging from palynology of archaeological sites (8.0-2.8 ka BP). Holocene 2019, in press.

28. Willcox, G. Evidence for plant exploitation and vegetation history from three Early Neolithic pre-pottery sites on the Euphrates (Syria). Veget. Hist. Archaeobot. 1996, 5, 143-152. [CrossRef] 
29. Mercuri, A.M.; Sadori, L.; Blasi, C. Archaeobotany for cultural landscape and human impact reconstructions. Plant Biosyst. 2010, 144, 860-864. [CrossRef]

30. Miller, N.F. An archaeobotanical perspective on environment, plant use, agriculture, and interregional contact in South and Western Iran. IJAS 2011, 1, 1-8. [CrossRef]

31. Hunt, C.O.; Rabett, R.J. Holocene landscape intervention and plant food production strategies in island and mainland Southeast Asia. J. Archaeol. Sci. 2014, 51, 22-33. [CrossRef]

32. Pérez-Jordà, G.; Peña-Chocarro, L.; Picornell-Gelabert, L.; Carrión Marco, Y. Agriculture between the third and first millennium BC in the Balearic Islands: The archaeobotanical data. Veget. Hist. Archaeobot. 2018, 27, 253-265. [CrossRef]

33. Mercuri, A.M.; Marignani, M.; Sadori, L. 2013 Palynology: The bridge between paleoecology and ecology for the understanding of human-induced global changes in the Mediterranean Area. Ann. Bot. 2013, 3, 107-113. [CrossRef]

34. Izdebski, A.; Holmgren, K.; Weiberg, E.; Stocker, S.R.; Büntgen, U.; Florenzano, A.; Gogou, A.; Leroy, S.A.; Luterbacher, J.; Martrat, B.; et al. Realising consilience: How better communication between archaeologists, historians and natural scientists can transform the study of past climate change in the Mediterranean. Quat. Sci. Rev. 2016, 136, 5-22. [CrossRef]

35. Hjelle, K.L.; Kaland, S.; Kvamme, M.; Lødøen, T.K.; Natlandsmyr, B. Ecology and long-term land-use, paleoecology and archaeology-The usefulness of interdisciplinary studies for knowledge-based conservation and management of cultural landscapes. Int. J. Biodivers. Sci. Ecosyst. Serv. Manag. 2012, 8, 321-337. [CrossRef]

36. Marignani, M.; Chiarucci, A.; Sadori, L.; Mercuri, A.M. Natural and human impact in Mediterranean landscapes: An intriguing puzzle or only a question of time? Plant Biosyst. 2017, 151, 900-905. [CrossRef]

(C) 2019 by the authors. Licensee MDPI, Basel, Switzerland. This article is an open access article distributed under the terms and conditions of the Creative Commons Attribution (CC BY) license (http:/ / creativecommons.org/licenses/by/4.0/). 